This is the peer reviewed version of the following article: Colin R Moore, 'Obligations in the Shade: The Application of Fiduciary Directors' Duties to Shadow Directors', which has been accepted for publication in the Legal Studies journal. This article may be used for non-commercial purposes in accordance with Wiley Terms and Conditions for Self-Archiving.

\title{
Obligations in the Shade: The Application of Fiduciary Directors' Duties to Shadow Directors
}

\author{
Colin R Moore \\ Kent Law School, University of Kent
}

\begin{abstract}
This paper argues that shadow directors, as defined in English law, ought to owe the full range of directors' duties, both fiduciary and non-fiduciary, enacted in the Companies Act 2006 (CA 2006), ss 171-177, to the relevant company under their influence. Following the enactment of the recent Small Business, Enterprise and Employment Act (SBEEA) 2015, these general duties are likely to apply to shadow directors, although there is still a case to be made as to why shadow directors should owe fiduciary duties to the relevant company. It is argued here that such a relationship is fiduciary in nature, but the current approach deployed in the English courts, based upon the application of Finn's originally formulated 'undertaking' test alone, is inadequate.

Given these inadequacies, it is proposed that the Canadian 'power and discretion' test be deployed alongside the 'undertaking' test, in order to provide a far more comprehensive justification for the application of fiduciary obligations to shadow directors. This position is supported by establishing a theoretical basis for the 'power and discretion' test, via Paul Miller's 'fiduciary powers theory', as well as considering the application of such a test to shadow directors.
\end{abstract}

\section{INTRODUCTION}

English company law recognises three basic categories of director: de jure directors who have been properly appointed, de facto directors who act as directors despite their lack of appointment and shadow directors, who exercise indirect control over the company by issuing instructions to obedient de jure directors. Given the pivotal role played by company directors in relation to corporate governance, it is vital that the power wielded by all types of directors is subject to regulation via the directors' duties. The seven directors' general duties from the Companies Act Companies Act 2006 (CA 2006), Pt X, ss 171-77 usually provide the primary source of both duty and potential liability for 
directors, notwithstanding other potential liability in the event of insolvency, ${ }^{1}$ or in circumstances where a director has acted whilst disqualified. ${ }^{2}$ The directors' general duties facilitate, for example, the application of equitable remedies against a director who exploits a profitable 'corporate opportunity' that rightfully belongs to the company, ${ }^{3}$ engages in self-dealing, ${ }^{4}$ or accepts bribes or other benefits from third parties. ${ }^{5}$ Furthermore, the general duties also require that the director concerns promotes the success of the company, ${ }^{6}$ as well as acting within powers defined in the company's constitution, ${ }^{7}$ amongst a range of other duties. A breach of directors' duties generates potential for claims on behalf of the company against the errant director, by a range of interested actors associated with the company, including the board of directors itself, shareholders by majority resolution, or minority shareholders via a statutory derivative action. ${ }^{8}$ Consequently, the normative claim made here is that shadow directors ought to owe the full range of directors' duties to the company, due to the important accountability structures such duties provide.

The problem is that whilst de jure and de facto directors clearly owe directors' fiduciary duties to a company, ${ }^{9}$ the position in relation to shadow directors has been the subject of a number of conflicting judicial decisions. Shadow directors clearly owe some specific statutory duties to the company in English law, as explored fully below, ${ }^{10}$ yet the scope and application of the general directors' duties

\footnotetext{
${ }^{1}$ See generally Insolvency Act 1986, Part IV, Ch X.

${ }^{2}$ See Company Directors Disqualification Act 1986, s 15.

${ }^{3}$ CA 2006, s 175.

${ }^{4}$ CA 2006, s 177.

${ }^{5}$ CA 2006, s 176.

${ }^{6}$ CA 2006, s 172.

${ }^{7}$ CA 2006, s 171.

${ }^{8}$ CA 2006, s 260.

${ }^{9}$ It has long been established that de jure directors owe fiduciary duties to the company, for example see: Aberdeen Railway Co v Blaikie Bros (1854) 1 Macq. 461, Parker v Mckenna (1874) LR 10 Ch App 96, Regal Hastings $v$ Gulliver [1967] 2 AC 134 and Guinness plc v Saunders [1990] 2 AC 663. This has also been established in relation to de facto directors, for example in Ultraframe (UK) Ltd v Fielding [2005] EWHC 1638 (Ch) and Re: Canadian Land Reclaiming \& Colonizing Co (1880) 14 Ch D 660, at 670 and 673 amongst others. See generally: J McGhee (ed) Snell's Equity (London: Thomson Reuters, 32 ${ }^{\text {nd }}$ ed, 2010) para 7-004.

${ }^{10}$ For example see CA 2006, s 187 in relation to the shadow directors' duty to declare an interest in an existing transaction.
} 
has been more problematic, since until recently the general duties applied to shadow directors, according to CA 2006, s $170(5)$, 'to the extent that, the corresponding common law rules or equitable principles so apply'. ${ }^{11}$ Happily, the recent Small Business, Enterprise and Employment Act (SBEEA) 2015, also considered in detail below, has substituted a new CA 2006, s 170(5), which provides that, 'The general duties apply to a shadow director of a company where and to the extent that they are capable of so applying', which clearly suggests that in the majority of circumstances the directors' general duties will apply to shadow directors. Given that almost all of the general directors' duties are probably fiduciary in nature, with the exception of the codification of negligence under the duty to 'exercise reasonable, care, skill and diligence', ${ }^{12}$ this also appears to suggest that the relationship between shadow directors and the company will be fiduciary in nature. However, the question arises as to why the shadow director - company relationship should now be classed as fiduciary in nature, given the previously conflicting case law on the matter.

The identification of fiduciaries in English law rests primarily on the presence of one of the previouslyestablished settled categories of fiduciary relationship (the status or relationship-based fiduciary) and, unlike de jure and de facto directors, the relationship between a shadow director and a company has yet to become settled. This is perhaps unsurprising given that the term 'shadow director' was first used as short-hand for the definition in the Companies Act 1980 (CA 1980), ${ }^{13}$ despite the concept itself having existed for nearly a century. ${ }^{14}$ Outside of the accepted categories of fiduciary relationships, fiduciary duties are also recognised on an individual factual basis, ${ }^{15}$ when an individual makes an

11 CA 2006, s 170(5) (now repealed). See below for a full discussion of how s 170 was altered after recommendations made by the Law Society. See also: I Moore 'Duties of a shadow director: recent developments considered' (2013) 345 CLN 1, at 2-3.

${ }^{12}$ CA 2006, s 174.

${ }^{13}$ CA 1980, s 63. See also P Davies and S Worthington Gower \& Davies: Principles of Modern Company Law (London: Sweet \& Maxwell, 9th edn, 2012) p 513.

${ }^{14}$ Since Companies (Particulars as to Directors) Act 1917, s 3.

${ }^{15}$ See generally McGhee, above $n 9$, para 7-006. Cases where a fiduciary relationship has been found on a factual basis in England include O'Sullivan v Management Agency \& Music Ltd [1985] 1 QB 428, where a manager of a young musician was found to owe fiduciary duties, English $v$ Dedham Vale Properties Ltd [1978] 1 WLR 93, where a prospective purchaser of a property owed fiduciary duties to the owner of the property by virtue of applying 
express or implied undertaking to act as a fiduciary (fact-based fiduciaries). This so-called 'undertaking' test has also been deployed on several occasions to determine the general fiduciary status of shadow directors, which has led to highly inconsistent results. The first part of this paper will demonstrate that, as evidenced by an analysis of the English cases of Yukong Line, ${ }^{16}$ Ultraframe ${ }^{17}$ and Vivendi SA v Richards ${ }^{18}$ that the presence or absence of an undertaking alone is an inadequate basis for the general determination of the fiduciary status of shadow directors. The problem is that, even where the wider 'assumption of responsibility' variant of the 'undertaking' test is used, the question that the 'undertaking' test cannot answer directly is whether becoming a shadow director should be classified as a 'relevant undertaking' and therefore lead to the imposition of fiduciary duties. Consequently, the final justification of such a fiduciary relationship extends beyond the 'undertaking test' alone to encompass various considerations of inequality, dependence, loyalty, property relations, vulnerability, or trust, or to the making of analogies with other categories of fiduciary relationship. It will be argued that the justifications offered thus far by the courts to supplement the 'undertaking test', when determining the fiduciary status of shadow directors, are practically and theoretically flawed. These arguments will be made in the first part of the paper by exploring the emergence of the shadow director concept, before considering the theoretical basis for imposing fiduciary duties, followed by a critical examination of the 'undertaking test' both theoretically and in its practical application to shadow directors by the English courts.

The second part of this paper will argue that the Canadian 'power and discretion' test should be deployed to provide a principled justification for the presence of a fiduciary relationship between

\footnotetext{
for planning permission and Cobbetts LLP v Hodge [2009] EWHC 786 (Ch), where a senior employee was found to owe fiduciary duties to his employer.

${ }^{16}$ Yukong Line of Korea Ltd v Rendsburg Corp Investments of Liberia Inc [1998] 1 WLR 294.

${ }^{17}$ Ultraframe (UK) Ltd v Fielding [2005] EWHC 1638 (Ch).

${ }^{18}$ [2013] EWHC 3006 (Ch).
} 
shadow director and company. The 'fiduciary powers theory' of Paul Miller ${ }^{19}$ will be used to justify the application of the 'power and discretion test', and to argue that fiduciary relationships can be justified without resorting to wider legal, moral or public policy justifications. In examining the 'fiduciary powers theory' it will also be argued that despite shadow directors lack of direct legal control over the affairs of the company, nevertheless the practical influence that these individuals possess over the board of directors of the relevant company constitutes a form of fiduciary power and should be recognised as such. The application of the 'power and discretion' test in Canada will also be examined, both generally, and in terms of a potential application to shadow directors. Finally, it will argued that both the 'undertaking test' and 'power and discretion test', should be applied as part of a wider process for identifying shadow directors as fiduciaries.

\section{SHADOW DIRECTORS}

The basic statutory definition of a shadow director has remained unchanged for almost 100 years, being defined by a succession of Companies Acts as, 'a person in accordance with whose directions or instructions the directors of the company are accustomed to act', ${ }^{20}$ although the shadow director name itself was only first applied to the concept by the Companies Act (CA) 1980, s 63. However, the common law has developed a slightly more comprehensive definition, with Millet J (as he then was) in Re: Hydrodam (Corby) $L t d,{ }^{21}$ identifying four key requirements for shadow directors. Firstly both the de jure and de facto directors of the company must be identified, secondly that the individual concerned must have directed those directors how to act, thirdly that the directors acted in accordance with the instructions given and fourthly that the directors were accustomed to act in this

\footnotetext{
${ }^{19}$ P Miller 'A Theory of Fiduciary Liability' (2011) 56 McGill LJ 235; 'Justifying Fiduciary Duties' (2013) 58 McGill L 969; 'The Fiduciary Relationship' in A Gold and P Miller (eds) Philosophical Foundations of Fiduciary Law (Oxford: Oxford University Press, 2014) p 63.

${ }^{20}$ This definition was first introduced by the Companies (Particulars as to Directors) Act 1917, s 3. Prior to CA 2006 it was also used increasingly extensively in the Companies Acts of 1928, 1929, 1947, 1948, 1967, 1981, 1985 ,

${ }^{21}[1994]$ BCC 161.
} 
manner. ${ }^{22}$ Crucially, Millet also emphasises that the Board of Directors must be 'claiming and purporting' to act in this manner, as well as failing to exercise any discretion or judgement of their own. ${ }^{23}$

Despite the above definitions, a clear tension exists within the shadow director common law jurisprudence as to the level of control that needs to be exercised by the individual concerned, in relation to the board of directors, before the shadow director label will be applied. In the influential case of Deverell, ${ }^{24}$ Morritt J found that influence did not need to be exercised over the entire field of corporate activities and whilst it is sufficient to show that the de jure directors cast themselves in a subservient role, there was no requirement to demonstrate that they had done this in all circumstances. ${ }^{25}$ The court also highlighted that it was dangerous to use epithets to describe the board, such as 'cat's paw, puppet or dancer to the tune of the shadow director', given that this suggested a greater degree and quality of control then the statutory definition actually required. ${ }^{26}$ However, It seems that in Deverell that the notion of 'accustomed to act' was somewhat under-played, given that earlier cases had found that control of the board, or at least a majority of the board, was needed in order for an individual to become a shadow director. ${ }^{27}$ Subsequent case law, ${ }^{28}$ and indeed the important later case of Ultraframe ${ }^{29}$ has also suggested that control of the board is needed, since the underlying policy ground of the statute was to ensure that those who effectively control the activities of a company were subject to the same statutory liabilities as a de jure director. ${ }^{30}$ It should

\footnotetext{
22 [1994] BCC 161 at 163.

$23 \mathrm{lbid}$.

${ }^{24}$ Secretary of State for Trade and Industry v Deverell [2001] Ch 340.

$25 \mathrm{lbid}$, at para 35.

${ }^{26} \mathrm{lbid}$, at para 36.

${ }^{27}$ See re Lo-Line Electric Motors Ltd [1988] Ch 477, at 489 (per Sir Nicolas Browne-Wilkinson V.C.), re Unisoft Group Ltd (No. 3) [1994] 1 BCLC 609, at 620 (per Harman J), re Hydrodam (Corby) Ltd [1994] 2 BCLC 180 at 183 (per Millett J) and Secretary of State for Trade and Industry v Laing [1996] 2 BCLC 324 (per Evans-Lombe J). ${ }^{28}$ Lord v Sinai Securities Ltd [2004] EWHC 1764 (Ch), [2004] BCC 986, at 993, para 27; See also the Privy Council decision in Kuwait Asia Bank EC v National Mutual Life Nominees Ltd [1991] 1 AC 187.

${ }^{29}$ Ultraframe (UK) Ltd v Fielding [2005] EWHC 1638 (Ch).

${ }^{30} \mathrm{Ibid}$ at para $1270-1272$ (per Lewison J).
} 
also be noted that a shadow director need not act in an indirect, covert, or undercover manner, despite Millet J's statement in Hydrodam that a shadow director claims not to be a director and instead 'lurks in the shadows, hiding behind others', ${ }^{31}$ given that the Court of Appeal in Deverell emphasised that whilst a shadow director may frequently lurk in the shadows, this is not an attribute that is specifically required. ${ }^{32}$

Given that the shadow director, according to the common law at least, is a key influential figure within the unofficial hierarchy of the relevant company, by virtue of having practical, although not formally legal, control of the Board of Directors, it is perhaps surprising that, unlike de facto directors, ${ }^{33}$ shadow directors have never been fully equated with the de jure director concept. Instead only certain statutory provisions from the Companies Acts apply to shadow directors, with such an approach being traceable to the emergence of the shadow director connect in the early twentieth century. The first manifestation of the shadow director concept appeared in the Companies (Particulars as to Directors) Act 1917 (CPDA 1917), s. 3 as a response to specific wartime concerns. The problem was, as expressed during the relevant parliamentary debates, ${ }^{34}$ that foreign or 'alien' influences could potentially take subversive control of British companies. Whilst the Companies (Consolidation) Act (CCA) 1908 required a list of directors of firms to be kept and any changes to be reported to the registrar of companies, ${ }^{35}$ as well as the submission of an annual return, ${ }^{36}$ the potential still existed for dummy directors to be appointed to ensure that the names of certain (presumably foreign) individuals were

\footnotetext{
${ }^{31}$ [1994] 2 BCLC 1 at $\mathrm{p} 183$. This position was also accepted by Evans-Lombe J in Secretary of State for Trade and Industry $v$ Laing [1996] 2 BCLC 324 and by Etherton J in Secretary of State for Trade and Industry v Hollier [2006] EWHC 1804 (Ch), [2007] BCC 11.

${ }^{32}$ Secretary of State for Trade and Industry v Deverell [2001] Ch 340 at para 36 (per Morritt L).

${ }^{33}$ See CA 2006, s 250 . The comparison between de facto directors and shadow directors is examined in a later section.

${ }^{34}$ The purpose was described in a speech by Lord Hylton (Lord-in-Waiting) during the second reading of the Company (Particulars as to Directors) Bill in the House of Lords. HL Deb 3 July 1917, vol 25, col 749.

${ }^{35}$ CCA 1908, s 75. This section also applied to managers.

${ }^{36}$ CCA 1908, s 16. Under CCA, s 274, companies incorporated outside of the UK, but establishing business premises within the UK, also had to submit a list of directors, amongst other details, to the registrar of companies within one months of establishing such UK premises.
} 
kept from the required list. Consequently CPDA 1917, s 3 attempted to allay this fear by extending these notification requirements to those individuals that would now be described as shadow directors. ${ }^{37}$ Subsequently this yet-to-be-named shadow director concept found increasing application in the later Companies Acts, ${ }^{38}$ with the now-named shadow director concept being used extensively in CA 2006, as detailed below, as well as the Company Directors Disqualification Act 1986 (CDDA 1986) ${ }^{39}$ and the Insolvency Act 1986 (IA 1986), ${ }^{40}$ with the shadow director case law being applicable across all three instances.

The use of the shadow director concept in CA 2006 is, unsurprisingly, primarily concentrated in Part 10 of the act, titled 'A Company's Directors', although the term is also elsewhere in the act to ensure liability will exist for shadow directors' defaults in the same manner as other directors. This liability arises in relation to provisions concerning company naming requirements, ${ }^{41}$ unauthorised corporate political donations,${ }^{42}$ company secretary rules, ${ }^{43}$ delivery of the required annual return to Companies House, ${ }^{44}$ disclosure of information provisions ${ }^{45}$ and when restoring a company to the Register of Companies. ${ }^{46}$ Derivative claims, made by an individual member or members on behalf of the company,

\footnotetext{
${ }^{37}$ CDPA 1917, s 3 also used the shadow director concept to extend rules relating to the annual return and register of directors defaults (amending Companies (Consolidation) Act 1908, s 26 and s 75 respectively).

${ }^{38}$ For example, CA 1928 extends shadow director liability to liquidation offences and fraudulent trading in CA 1928 , s 73 and s 75 respectively, as well as in relation to director disqualification rules under CA 1928, s 75 . The 1928 act also added the shadow director exemption for advice given in a professional capacity, see CA 1928, s 94. These provisions were consolidated by CA 1929 just one year later.

${ }^{39}$ DDA 1986, s 4, s 6, s 8, s 9E, s 22, s 22A, s 22B, s 22C, s 22E, s 22F, and Sch 1 Pt 2 . See also DDA 1986, s 7A, s $8 Z A, s 8 Z C, s$ 8ZD, s 8ZE and s 12C, which were enacted by SBEEA 2015 but are not yet fully in force.

${ }^{40}$ IA 1986, s 6A, s 206, s 208, s 210, s 211, s 214, s 214A, s 249, s 251, and Sch A1, Pt II, Cl 41, Cl 42, Cl 60A.

${ }^{41}$ CA 2006, s 63(2), s 68(5), s 75(5), s 76(6) and s 84(2).

${ }^{42}$ CA 2006, s 379(1).

${ }^{43}$ CA 2006, s 272(6)(b), s 275(6)(b) and s 276(3).

${ }^{44}$ CA 2006, s 858(1).

${ }^{45}$ There are a couple disclosure of information provisions in CA 2006, Pt 15 (Accounts and Reports). These relate to abuse of information supplied by HMRC for a specific purpose, CA 2006, s 458(6) and disclosure of private information obtained under compulsory powers, CA 2006, s 460(6). Also under CA 2006, Pt 16 (Audit), if an auditor leaves office then the statement made on leaving office under CA 2006, s 519, must be forwarded to the registrar. If any of these sections are breached by a body corporate, then any shadow directors will be potentially liable alongside other officers of the company.

${ }^{46}$ CA 2006, s 1028A (administrative restoration) and s 1032A (restoration by a court), as inserted into CA 2006 by SBEEA 2015.
} 
may also be brought against a shadow director in relation to a relevant breach. ${ }^{47}$ In CA 2006, Pt 10 itself, aside from the issue of the directors' general duties ( $\mathrm{Ch}$ 2) considered below, liability for default extents to shadow directors in relation to the appointment and registration of directors (Ch 1), ${ }^{48}$ directors' service contracts (Ch 5), ${ }^{49}$ as well in relation to the special provisions for directors of quoted companies ( $\mathrm{Ch} 4 \mathrm{~A})$ and the recording requirements and procedures for single member companies ( $\mathrm{Ch}$ 6). ${ }^{50}$ The directors' duty to declare an interest in an existing transaction or arrangement (Ch 3$),{ }^{51}$ rules on transactions requiring members approval $(\mathrm{Ch} 4),{ }^{52}$ general rules on the ratification of directors' acts $^{53}$ and the restriction on using the s 247 power (Ch 9) to benefit directors with a resolution of the company, ${ }^{54}$ all also apply to shadow directors. Evidently the shadow director concept is of vital importance within CA 2006, with directors' duties and liability extending to shadow directors in many circumstances, even though the two concepts are not directly equated.

Notwithstanding the importance of the shadow director concept in CA 2006, concern has emerged as to how wide the might become, a false apprehension caused, it is submitted, due to excessive focus on the statutory definition of the shadow director conception, without reference to the clarifications that emerge from the case law described above. This problem is typified by the question of the applicability of the general directors' duties ${ }^{55}$ to shadow directors, which proved controversial at the

\footnotetext{
${ }^{47}$ Under CA 2006, s 260(3) a relevant breach arises 'from an actual or proposed act or omission involving negligence, default, breach of duty or breach of trust by a director of the company.'

${ }^{48}$ CA 2006, s 156(6), s 157(5)(b), s 162(6), s 165(4) and s 167(4). Note that the register of directors itself does not need to name shadow directors, but shadow directors will be liable for defaults in relation to the register and other defaults as listed in these sections (See CA 2006 explanatory notes para 289).

${ }^{49}$ CA 2006, s 230 extends the whole of Pt 10, Ch 5 to shadow directors.

${ }^{50}$ CA 2006, s 231(5).

${ }^{51}$ CA 2006, s 187

${ }^{52}$ The following are subject to approval: directors' service contracts (CA 2006, ss 188-189), substantial property transactions (CA 2006, ss 190-196), loans (CA 2006, ss 197-214) and payments for loss of office (CA 2006, ss 215 222). A shadow director is treated as a director for all of these sections, by virtue of CA 2006, s 223(1).

${ }^{53}$ CA 2006, s 239

${ }^{54}$ The directors of a company have powers under CA 2006, s 247 to make provisions for employees, 'on cessation or transfer of business'. Whilst this power itself does not extend to shadow directors, under CA 2006, s 247(5)(b), any payments to directors, former directors or shadow directors must be authorised by a resolution of the company and not simply by a resolution of the directors.

${ }^{55}$ CA 2006, Pt 10, Ch 2.
} 
time of the enactment of CA 2006, despite support from the majority of those responding to the Law Commission's earlier consultation, ${ }^{56}$ the Company Law Review Steering Group ${ }^{57}$ and in the DTI's draft bill. ${ }^{58}$ Due presumably to objections raised in response to the DTI consultation by the CBI and Law Society, who both expressed concerns that the application of the general duties might give rise to problems in practice, such as lending banks potentially becoming shadow directors, ${ }^{59}$ the draft bill presented in Parliament did not extend the general duties to shadow directors. ${ }^{60}$ Instead, as described above, CA 2006, s 170(5), as enacted, left the decision about such an application to the courts on the basis that this would allow further development of the shadow director concept by the courts. ${ }^{61}$

At the time of enactment of CA 2006 the leading case of Ultraframe had held that shadow directors were not fiduciaries, ${ }^{62}$ and therefore the majority of the general duties would not apply to shadow directors. This undoubtedly influenced the shape of CA 2006, s 170(5), as originally enacted, ${ }^{63}$ but following the later decision in Vivendi, it was established that shadow directors did owe at least some fiduciary duties to the company. ${ }^{64}$ Consequently, the extension, as noted above, of the general

\footnotetext{
${ }^{56}$ See The Law Commission and Scottish Law Commission (LAW COM No 261) (SCOT LAW COM No 173) Company Directors: Regulating Conflicts of Interests and Formulating a Statement of Duties (September 1999), p 11. The Law Commission report itself did not take a position on whether the general duties should apply to shadow directors, on the basis that this was a matter for the Company Law Review.

${ }^{57}$ Company Law Review Steering Group, Modern Company Law for a Competitive Economy: Completing the Structure (November 2000), para 4.7 and Modern Company Law for a Competitive Economy Final Report: Final Report (URN 01/942 and URN 01/943) p 135.

${ }^{58}$ Although the draft bill did state under clause B1(2) that the general duties would be applied to shadow directors 'subject to any necessary adaptations'. See White Paper, Company Law Reform (March 2015) CM 6456. ${ }^{59}$ DTI Company Law Reform White Paper: CBI Response (dated June 2005), p 25; The response of the Law Society's Company Law Committee, the Company Law Sub-Committee of the City of London Law Society and the Law Reform Committee of the General Council of the Bar (dated June 2005), p 34. Both documents available at: http://webarchive.nationalarchives.gov.uk/20121029131934/http://www.bis.gov.uk/files/file25401.zip. Date Accessed 17/07/2015.

${ }^{60}$ Company Law Reform Bill (HL Bill 108-I) as first introduced: 16 May 2006, Cl 153(5). See also speech of Lord Goldsmith (HL Deb 6 Feb 2006: Column GC247) where he explicitly refers to 'several negative consultation responses'.

${ }^{61}$ Speech of Lord Goldsmith (HL Deb 6 Feb 2006: Column GC248).

${ }^{62}$ Ultraframe (UK) Ltd v Fielding [2005] EWHC 1638 (Ch). This case is discussed in detail below.

${ }^{63}$ Although Lord Goldsmith (HL Deb 6 Feb 2006: Column GC247) does not mention Ultraframe by name, he does seem to suggest that recent case law had influenced the government position.

${ }^{64}$ Vivendi SA v Richards [2013] EWHC 3006 (Ch). This case is also discussed in detail below.
} 
directors duties, by a new CA 2006, s 170(5), created by SBEEA 2015, ${ }^{65}$ applying the general directors' duties to shadow directors, 'to the extent they are capable of so applying', simply codified the position that had been established in case law, although such a codification still met with a certain level of opposition both from evidence submitted to the Public Bill Committee ${ }^{66}$ and in the Parliamentary debates. ${ }^{67}$

While the Department of Business, Innovation and Skills (BIS) suggested that SBEEA 2015, Pt 7, was concerned with increasing transparency within companies, ${ }^{68}$ and other provisions within this part, such as the creation of a 'Register of people with significant control' and the requirement that all company directors be natural persons, ${ }^{69}$ seem to support this goal, the final effect of SBEEA 2015 on shadow director liability is not yet clear. This is due to the extension of shadow director exclusion beyond those giving advice in a professional context, which has traditionally been included, ${ }^{70}$ to those carrying out a statutory function, as well as those acting within their capacity as a government minister. ${ }^{71}$ Additionally, the Secretary of State is empowered to make provisions as the application of

\footnotetext{
${ }^{65}$ SBEEA 2015, s 89(1).

${ }^{66}$ See Public Bill Committee, Small Business, Enterprise and Employment Bill: Written Evidence (October 2014). The British Private Equity and Venture Capital Association ( $p$ 97) expressed concern that the application of the general duties in the manner proposed was too onerous on shadow directors. The Quoted Companies Alliance ( $p$ 106), suggested that it was dangerous for the general duties to be applied to shadow directors on the basis that they are not really directors, but instead persons that policy imposes certain liabilities on. It should be noted that the Law Society now supported the imposition of these general duties on shadow directors.

${ }^{67}$ A key concern expressed in the House of Lords, by Lord Flight and Lord Leigh of Hurley, was that the phrase 'to the extent they are capable of so applying', left the courts with little discretion as to whether the individual general duties would apply to shadow directors, they proposed instead an amendment (no 51) to impose the duties 'to the extent it is reasonable, just and equitable for any such general duty to apply.' However, they were persuaded to withdraw the amendment following immediate reassurances from Baroness Neville-Rolfe (Minister for Intellectual Property and Parliamentary Under-Secretary-of-State) that the courts would retain sufficient flexibility in determining which duties would apply to shadow directors. This opinion was subsequently confirmed by letter. (See HL Deb 19 Jan 2015:Column GC337-GC341 and letter dated 5 February 2015 to Lord Flight and Lord Leigh of Hurley from Baroness Neville-Rolfe, Minister for Intellectual Property, BIS).

${ }^{68}$ See SBEEA 2015, Explanatory notes, para 97.

${ }^{69}$ SBEEA 2015, ss 81-82 and Sch 3 provides enabling legislation for the future introduction of the People with Significant Control (PCS) register, while SBEEA 2015, s 87, requiring all directors to be natural person, is also not yet in force.

${ }^{70}$ Such an exclusion has existed since CA 1928 and is current found in CA 2006, s 251(2).

${ }^{71}$ SBEEA 2015, s 90 amends IA 1986, s 251, CDDA 1986, s 22(5) and s 251(2) to include these additional exclusions from the shadow director definition.
} 
the general directors' duties to shadow directors ${ }^{72}$ and to rule whether or not a particular general duty will apply to shadow directors. ${ }^{73}$ Despite these provisions, it appears that the general directors' duties will be allowed to usually apply to shadow directors, save for circumstances where the Secretary of State chooses to intervene. Clearly, despite the failure to equate shadow directors with de jure and de facto directors in CA 2006, shadow directors have the same responsibilities and liabilities as de jure directors in many areas. However, such similarity alone does not provide a full justification for imposing fiduciary duties on shadow directors, particularly considering the lack of legal control possessed by the shadow director. The imposition of fiduciary duties still needs to be both theoretical justifiable and practically implemented, the requirements for which will be examined in the remainder of the paper.

\section{FIDUCIARY THEORY}

Prior to examining the judicial approach to the application of fiduciary duties to shadow directors, it is first useful to briefly identify the theoretical arguments that have developed regarding the nature of fiduciary duties. ${ }^{74}$ Several possible justifications for fiduciary duties will be identified, ${ }^{75}$ to facilitate the later theoretical contextualisation of a number of judicial decisions relating to the fiduciary duties of shadow directors. The key problem is that historically judges were prepared to, and to some extent still do, impose fiduciary duties between individuals providing a relevant relationship could be found,

\footnotetext{
72 SBEEA 2015, s 89(2).

73 SBEEA 2015, s 89(3).

${ }^{74}$ Good general theoretical summaries and critiques include: A Gold and P Miller (eds) Philosophical Foundations of Fiduciary Law (Oxford: Oxford University Press, 2014), Frankel Fiduciary Law (Oxford: OUP, 2011), Miller (2013), above n 20, pp 975-1004, L Rotman Fiduciary Law (Toronto: Thomson Carswell, 2005) pp 53 - 152, J Shepherd The Law of Fiduciaries (Toronto: Carswell, 1981) pp 51 - 92 and P Finn Fiduciary Obligations (Sydney: The Law Book Company Ltd, 1977)

75 See P Birks 'Equity in the Modern Law: An Exercise in Taxonomy' (1996) 26 W Aust L Rev 1, at 3 in relation to problems with the fiduciary concept. See also D DeMott 'Fiduciary Obligations Under Intellectual Siege' (1992) 30 Osgoode Hall LJ 471 and Rotman, above n 157, pp 12-13.
} 
without explaining why such a relationship is deemed to be fiduciary in nature. ${ }^{76}$ In order to fill the gap created by the courts, a number of theoretical justifications have subsequently been provided by academics for justifying the application of these duties, although it should be noted that, as is obvious from the plethora of approaches noted here, the search for an over-arching theory of fiduciary obligation is far from complete.

Three primary strategies have emerged for justifying fiduciary relationships: reductivist, instrumentalist and juridical. The reductivist justification denies that fiduciary relationships are unique, often using economic analysis in the form of agency theory, ${ }^{77}$ and attempts to justify fiduciary duties with reference to other facets of private law. Most justifications of this type have primarily been developed from contract theory, ${ }^{78}$ and have been widely criticised, ${ }^{79}$ but others have been based on other facets of private law such as property, ${ }^{80}$ unjust enrichment ${ }^{81}$ and tort. $^{82}$ Conversely,

${ }^{76}$ For a discussion of this problem and the early development of fiduciary law see L Sealy, 'Fiduciary Relationships' [1962] CLJ 69; Rotman, above n 157, pp 56-79 and P Parkinson (ed) The Principles of Equity (Sydney: LBC Information Services, 1996), pp 336-342.

${ }^{77}$ See F Easterbrook and D Fischel 'Contract and Fiduciary Duty' (1993) 36(1) JL \& Econ 425, at 438; Miller (2011), above $n$ 20, at 251-252; R Sitkoff 'An Economic Theory of Fiduciary Law' in A Gold and P Miller (eds) Philosophical Foundations of Fiduciary Law (Oxford: Oxford University Press, 2014) p 197; R Cooter and B Freedman, 'The Fiduciary Relationship: Its Economic Character and Legal Consequences' (1991) 66 NYULR 1045; F Easterbrook and D Fischel 'The Corporate Contract' (1989) 89(7) Colum L Rev 1416 and M Jensen and W Meckling 'Theory of the Firm: Managerial Behavior, Agency Costs and Ownership Structure' (1976) $3 \mathrm{~J}$ Fin Econ 305.

${ }^{78}$ Cooter and Freedman, above n 77; Easterbrook and Fischel, above n 77, and J Langbein 'The Contractarian Basis of the Law of Trusts' (1995) 105(3) Yale LJ 625.

${ }^{79}$ See Miller (2013), above n 20, pp 982-984; Rotman, above n 157, pp 108-126; Brudney 'Contract and Fiduciary Duty' (1997) 38(4) BCL Rev 595, at 605; W Bratton 'The 'Nexus of Contracts' Corporation: A Critical Appraisal' (1989) 74(3) Cornell L Rev 407; Tamar Frankel 'Fiduciary Duties as Default Rules' (1995) 74(4) Or L Rev 1209; Scott FitzGibbon 'Fiduciary Relationships Are Not Contracts' (1999) 82(2) Marq L Rev 303; M Eisenberg, 'Corporate Law and Social Norms' (1999) 99(5) Colum L Rev 1253; Gregory S Alexander, 'A Cognitive Theory of Fiduciary Relationships' (2000) 85(3) Cornell L Rev 767; Conaglen, Fiduciary Loyalty (Oxford: Hart Publishing 2011) pp 214-21 and S Galoob and E Leib 'Intentions, Compliance, and Fiduciary Obligation' (2014) 20(2) Legal Theory 106.

${ }^{80}$ This theory will be discussed in relation to its application in the Ultraframe case.

${ }^{81}$ Gareth Jones 'Unjust Enrichment and the Fiduciary's Duty of Loyalty' (1968) 84 LQR 472.

${ }^{82}$ See Miller (2013), above $n$ 20, at 991-994 for an analysis of a potential tort basis for fiduciary obligations. See also Frankel, above n 157, pp 240-241. Matthew Conaglen lists the following examples: Birks, 'The Concept of a Civil Wrong' in Owen (ed) Philosophical Foundations of Tort Law (Oxford: OUP, 1995) p 31 at 35; P Birks 'Definition and Division: a Meditation on Institutes 3.13' in P Birks (ed), The Classification of Obligations (1997) p 1, p 14 (referring to them as "meta-torts"); A Burrows, Understanding the Law of Obligations: Essays on Contract, Tort and Restitution (1998), pp 14 and 31 and M Conaglen 'The Nature and Function of Fiduciary Loyalty' (2005) 121 LQR 452. 
instrumentalist justifications ${ }^{83}$ accept the unique nature of the fiduciary relationship, but deny or decline to consider that a single essence or property can define fiduciary relationships, ${ }^{84}$ instead justifying fiduciary relationships with reference to an 'independently-valuable end'. Such justifications have also attracted much criticism and have been variously based on morality ${ }^{85}$ (including loyalty ${ }^{86}$ or trust $^{87}$ based justifications), public policy, ${ }^{88}$ or other ends based upon 'a legal principle or a consideration peculiar to legal institutions or the integrity of law. ${ }^{189}$ While it is impossible to state conclusively that juridical or instrumentalist could not produce a compelling justification for fiduciary relationships, it is clear that those mentioned so far have clearly identifiable weaknesses and therefore it is proposed that an alternative juridical ought to be deployed. Juridical justifications accept that fiduciary duties are unique, but are justifiable based upon the formal characteristics of the fiduciary relationship itself ${ }^{90}$ and can provide a justification for the Canadian 'power and discretion test', via

\footnotetext{
${ }^{83}$ See Miller (2013), above $n$ 20, p 994. See generally R Summers Instrumentalism and American Legal Theory (Ithaca: Cornell University Press, 1982) and D Lyons 'Legal Formalism and Instrumentalism: A Pathological Study' (1981) 66(5) Cornell L Rev 949.

${ }^{84}$ D DeMott 'Breach of Fiduciary Duty: On Justifiable Expectations of Loyalty and Their Consequences' (2006) 48(4) Ariz L Rev 925, at 934-935 and J Glover 'The Identification of Fiduciaries' in Peter Birks (ed) Privacy and Loyalty (Oxford: Clarendon Press, 1997) p 269, p 275. For a critique of these views see See Miller (2013), above n 20, at 1010 and for a defence of fiduciary law as a separate legal category see Frankel, above n 82, pp 217242.

${ }^{85}$ For example see T Frankel 'Fiduciary Law' (1983) 71 Cal L Rev 795, at 829-30. For a criticism of morality as an instrumental justification see See Miller (2013), above n 20, pp 995-999.

${ }^{86}$ See the discussion of Ultraframe below for an analysis of loyalty-based justifications for fiduciary obligations.

${ }^{87}$ See Frankel, above $n$ 162, pp 6-12 and L Rotman, 'Fiduciary Law's "Holy Grail": Reconciling Theory and Practice in Fiduciary Jurisprudence' (2005) 91 Boston U LR 921, on the importance of trust or entrustment. See also L Mitchell 'The Naked Emperor: A Corporate Lawyer Looks at RUPA's Fiduciary Provisions' (1997) 54(2) Wash \& Lee L Rev 465, at 480-81 and R Flannigan 'The Fiduciary Obligation' (1989) 9(3) Oxford J Legal Stud 285, at 297. See Miller (2013), above n 20, pp 997-999 for a discussion of number of problems with the trust justification. For a discussion of trust as a general characteristic of fiduciary relationships see: $\mathrm{M}$ Harding 'Trust and Fiduciary Law' (2013) 33(1) OJLS 81.

${ }^{88}$ The potential for a public policy justification is discussed in relation to the Vivendi case.

${ }^{89}$ Miller (2013), above n 20, at 973. See P Birks, 'The Content of Fiduciary Obligations' (2000) 34 Lsr LR 3, Conaglen, above $n$ 79, and Conaglen, above $n$ 82, for arguments of this type. See Miller (2013), above n 20, pp 1001-4, Galoob and Leib, above $n$ 79, and J Edelman 'The Importance of the Fiduciary Undertaking' (2013) $7 \mathrm{~J} \mathrm{Eq}$ 128 , at $135-138$, for criticisms of Matthew Conaglen's argument.

${ }^{90}$ Miller (2013), above $\mathrm{n} 20$, at 973 explains that, 'Juridical justificatory argument aims to reveal the justificatory structure of the settled practices and principles of liability constitutive of a given legal form of an institution or mode of interaction'. For a further explanation of the concept of juridical justification, and a comparison with Zipursky's pragmatic conceptualism, plus Weinrib's formalist method, see Miller (2013), above n 20, pp 10071009. See also B Zipursky 'Pragmatic Conceptualism' (2000) 6(4) Legal Theory 457, at 459 and E Weinrib, The Idea of Private Law (Oxford: OUP, 2012) p 25. See generally E Weinrib 'Legal Formalism: On the Immanent Rationality of Law' (1988) 97(6) Yale LJ 949; E Weinrib, 'The Juridical Classification of Obligations' in P Birks (ed) The Classification of Obligations (Oxford: Clarendon Press, 1997) p 37, pp 37-56 and N Simmonds The Decline of Juridical Reason: Doctrine and Theory in the Legal Order (Manchester: Manchester University Press, 1984).
} 
Paul Miller's 'fiduciary powers theory' for justifying fiduciary relationships. ${ }^{91}$ Whilst a definitive theoretical justification cannot be provided for Paul Miller's theory, it is nevertheless argued that the theory does provide a sound justification for adopting the 'power and discretion' test alongside the 'undertaking test'. This is particularly pertinent given the difficulties suffered by the English courts in identifying whether shadow directors ought to be fiduciaries using the 'undertaking' test alone, as the next two sections will demonstrate.

\section{THE ORIGINAL ‘UNDERTAKING’ TEST}

Whilst a number of early cases posited a property-based justification for fiduciary duties, ${ }^{92}$ a key moment for fiduciary law generally arose when the American academic Austin W Scott asked himself rhetorically in 1949, 'Who is a fiduciary?'. His answer was somebody who had undertaken to act in the interests of another person, and thus the 'undertaking' test was born..$^{93}$ The writing of Australian academic and judge Paul Finn is also often cited in support of the concept of the 'undertaking test', although it should be noted that the oft-cited passage describing a fiduciary as, 'somebody who undertakes to act for or on behalf of another in some particular matter or matters, ${ }^{94}$ is a definition from which Finn subsequently retreated and his later alternative approach is considered below. Nevertheless in England, the 'undertaking test' has become the cornerstone for the identification of fact-based fiduciaries in the English jurisdiction, having received support from the Law Commission in $1995^{95}$ and the House of Lords in White $v$ Jones, ${ }^{96}$ albeit under the terminology of an 'assumption of

\footnotetext{
91 Shepherd, above n 157, pp 93-109 offers a similar power-based theory. For a functional based theory of fiduciary liability, with fiduciary law cast as part of equity's safety valve, 'aimed at countering opportunism', see H Smith 'Why Fiduciary Law is Equitable' in A Gold and P Miller (eds) Philosophical Foundations of Fiduciary Law (Oxford: Oxford University Press, 2014) p 261.

92 See Soar v Ashwell [1893] 2 QB 390 and Tintin Exploration Syndicate Ltd v Sandys (1947) 111 LT 41.

${ }^{93}$ A Scott 'The Fiduciary Principle' (1949) 37 Cal L Rev 539 at 540.

${ }^{94}$ Finn, above $n$ 157, p 201, para 467; For example cited by G Moffat Trusts Law (Cambridge: CUP, $5^{\text {th }}$ edn, 2009) p 839.

95 Fiduciary Duties and Regulatory Rules (Law Com no 236) (1995) para 1.3; See Moffat, above n 177, p 838.

96 [1995] 2 AC 207 at 271 (per Lord Browne-Wilkinson).
} 
responsibility'. In Bristol \& West Building Society v Mothew, ${ }^{97}$ Millet $\sqcup$ (as he then was) specifically adopted Finn's initial 'undertaking' formulation ${ }^{98}$ and subsequently such a formulation has been generally accepted by the English courts. ${ }^{99}$

While Scott deployed morality, in the form of loyalty, ${ }^{100}$ as a justification for the undertaking test, more recent vociferous support has come from the reductivist contract-based theory of Australian judge and academic James Edelman. He argues that it is only possible to understand when fiduciary duties will arise, 'if we conceive of them as obligations based upon manifestations of a voluntary undertaking to another'. Consequently, he suggests that the scope of the obligations depends upon the scope of the express or implied undertaking, and therefore fiduciary duties should be treated like any other express or implied term, 'by construction of the scope of voluntary undertakings,, ${ }^{101}$ using the standard principles of construction and implication. ${ }^{102}$ However, Edelman's justification has been criticised by Miller, firstly on the basis that whilst many fiduciary relationships are voluntarily undertaken, others are imposed constructively when the individual concerned undertakes particular actions, notably in England by CA 2006. Secondly, whilst consent reconciles fiduciary duties with the notion of personal autonomy, it would be an insufficient basis for establishing that one individual ought to serve another as a fiduciary, and does not provide sufficient grounds for imposing the key fiduciary duty of loyalty. Thirdly, whilst Edelman suggested that implication is warranted by 'trust, confidence, power, vulnerability and/or discretion', he failed to explain why these concepts provide support for implying fiduciary duties. Miller suggests that in fact Edelman's argument, 'appears to be

\footnotetext{
${ }^{97}$ [1998] Ch 1.

${ }^{98}$ Millet LJ at $\mathrm{p} 18$ stated, 'The concept encaptures a situation where one person is in a relationship with another which gives rise to a legitimate expectation, which equity will recognise, that the fiduciary will not utilise his or her position in such a way which is adverse to the interests of the principal'.

${ }^{99}$ English authorities for this statement include Arklow Investments Ltd v Maclean [2000] 1 WLR 594 at 599-600; Peskin v Anderson [2001] BCC 874 at para 34; Hooper v Gorvin [2001] WTLR 575 at 590; Kyrris v Oldham [2003] EWCA Civ 1506 [2004] BCC 111 at para 142; Button v Phelps [2006] EWHC 53 (Ch) at paras 58-61. See generally McGhee, above $n$ 9, para 7-005.

${ }^{100}$ See Scott, above $\mathrm{n} 936$, for numerous examples.

$101 \mathrm{~J}$ Edelman, 'When do fiduciary duties arise?' (2010) 126 LQR 30.

102 Ibid, p 30.
} 
that fiduciary duties are implied terms governing interactions that have the classic hallmarks of a fiduciary relationship' ${ }^{103}$ In other words the problem is that the undertaking test does not provide a full justification for the imposition of fiduciary duties, or even any sort of rationale for doing so. This then leads to practical application problems in the courts, as the next part of the analysis will demonstrate.

\section{THE DECISIONS IN YUKONG LINE AND ULTRAFRAME}

In terms of application of the 'undertaking test' to shadow directors, the earliest English case that considered the fiduciary duties of shadow directors, Yukong Line, ${ }^{104}$ fell into the 'historical trap' of defining the shadow director-company relationship as fiduciary without supplying a ratio decidendi for the decision. ${ }^{105}$ The 'undertaking test' was in fact first applied to shadow directors in Ultraframe, ${ }^{106}$ where Lewison J considered whether the relationship between a shadow director and the relevant company was fiduciary in nature. Prior to this application, Lewison J first identified that 'shadow director' was a narrower statutory concept then 'director', 107 thus justifying differential treatment of shadow directors compared to de jure and de facto directors. In terms of the 'undertaking' test itself, he adopted Millett LJ's formulation from Bristol \& West BS v Mothew, but emphasised that the key component of the fiduciary duty is loyalty, which required the presence of a direct relationship of trust and confidence between the company and the shadow director. ${ }^{108}$ Lewison J also suggested that,

\footnotetext{
${ }^{103}$ See Miller (2013), above $n$ 20, pp 986-987.

${ }^{104}$ At para 311.

${ }^{105}$ Rotman, above $\mathrm{n} 157$, pp 75-76 refers to this as 'innate recognition identification' or the 'I know one when I see one' approach. For a practical example see the Canadian case of Lefebvre $v$ Gardiner (1988) 27 BCLR (2d) 294 at para 17 (per Huddart J).

106 [2005] EWHC 1638 (Ch).

${ }^{107}$ At para 1279.

${ }^{108}$ At para 1286.
} 
'The indirect influence exerted by a paradigm shadow director who does not directly deal with or claim the right to deal directly with the company's assets will not usually, in my judgment, be enough to impose fiduciary duties upon him; although he will, of course be subject to those statutory duties and disabilities that the Companies Act creates. The case is the stronger where the shadow director has been acting throughout in furtherance of his own, rather than the company's, interests. ${ }^{109}$

The question of loyalty as an instrumental justification for fiduciary duties will be considered below, but two further observations can be made regarding Lewison J's statement, which illustrate problems with the decision in this case. Firstly, liability for breach of the fiduciary duty of loyalty is currently still strict, ${ }^{110}$ despite some judicial and academic observations that blameworthiness should be relevant, ${ }^{111}$ and so it would seem inconsistent, as the law stands, for motive to be relevant to shadow director fiduciary liability. Secondly, introducing loyalty as part of the formulation for finding fiduciary duties also seems to indicate that the undertaking test alone is insufficient for establishing whether a fiduciary relationship exists, given that the undertaking test provides no guidance on the concept of

\footnotetext{
${ }^{109}$ At para 1289.

${ }^{110}$ It has long been established that breaches of the fiduciary duty of loyalty are strict liability in nature, see: Keech v Sandford (1726) Sel Cas Ch 61 and Aberdeen Railway Co v Blaikie and (1854) 1 Macq 461 (HL). The strictness of the rule was confirmed in Boardman $v$ Phipps [1967] 2 AC 46, although the possibility of equitable accounting to reduce the liability of a fiduciary acting in good faith was emphasised, although the scope of the equitable accounting jurisdiction is likely to be limited according to Lord Goff in Guinness PIc v Saunders [1990] 2 AC 663 at 701, 'to those cases where it cannot have the effect of encouraging the trustees [or directors] in any way to put themselves in a position where their interests conflict with their duties at trustees [or directors]'. See generally Davies and Worthington, above n 13, pp 616-617.

${ }^{111}$ Robert Flannigan observes that judicial statements were made to this affect, albeit in obiter, in the Court of Appeal decision in Murad v Al-Saraj [2005] EWCA Civ 959 at para 82 (per Arden L) and paras 156-158 (per Clarke $\mathrm{U})$, although he observes that the stronger challenge is from academic commentators. He criticises academic challenges to the strict liability position from Gareth Jones, John Lowry (along and with various collaborators) and John Langbein, ultimately concluding that none of these challenges respond adequately to the detection concern or availability of consent issues that pervade the duty of loyalty in the fiduciary relationship. See: $\mathrm{R}$ Flannigan, 'The Strict Character of Fiduciary Liability' [2006] NZLR 215, see also R Flannigan, 'The Economics of Fiduciary Accountability' (2007) 32 Del J Corp L 393, for an economic analysis and justification of the strict liability rule.
} 
'relationship of trust and confidence', which is embodied by the concept of loyalty according to Lewison J.

Whilst loyalty can provide a morality-based instrumental justification for fiduciary obligations, and indeed has been the basis of a number of such justifications, ${ }^{112}$ a number of problems have been identified with deploying loyalty as a defining characteristic. Loyalty is almost as difficult to define as the fiduciary concept itself, ${ }^{113}$ it is a concept that also appears outside fiduciary relationships ${ }^{114}$ and it fails to provide a rationale for equitable intervention, ${ }^{115}$ so whilst it may be an important part of a fiduciary relationship, it alone cannot define the nature of a fiduciary relationship. ${ }^{116}$ In Ultraframe itself, Lewison J never really defined loyalty, but instead pursued a reductivist property-based justification for fiduciary duties, by applying trust law to fiduciaries generally. He referred to Paragon Finance $v B B$ Thakrar \& $C_{0},{ }^{117}$ where Millett $U$ differentiated between those who receive trust property knowing that another has a beneficial interest in the property, and therefore become trustees, as against those who simply participate in a fraud and may never receive the trust property at all and consequently are not trustees. ${ }^{118}$ Only those who have possessed the trust property can owe fiduciary duties, beyond this those in the second category will attract personal liability but are not fiduciaries, even though at times they have been confusingly referred to as 'constructive trustees' rather than the more comprehensible 'dishonest assistant'. Lewison J in Ultraframe placed shadow

\footnotetext{
${ }^{112}$ A number of moral justifications use philosopher Josiah Royce as a starting point. See J Royce, The Philosophy of Loyalty (New York: Macmillan Company, 1908) Ch 1); Demott, above n 167, p 925 and Scott, above n 176, p 540. See also E Scallen, 'Promises Broken v. Promises Betrayed: Metaphor, Analogy, and the New Fiduciary Principle' (1993) U III L Rev 897; Frankel, above n 858, p 830. See generally See Miller (2013), above n 20, p 995 and Rotman, above $\mathrm{n} 157$, pp 140-145.

${ }^{113}$ See Scallen, above n 112, p 909 and Rotman, above n 157, p 144.

${ }^{114}$ Rotman, above $\mathrm{n} 74, \mathrm{p} 143$ refers to J McCamus 'The Evolving Role of Fiduciary Obligation' in 1998-99, Meredith Lectures, Faculty of Law, McGill University (Cowansville: PQ: Yvon Blais, 2000) p 200.

${ }^{115}$ Rotman, above n 157, p 144 refers to J Glover Commercial Equity: Fiduciary Relationships (Sydney: Butterworths, 1995) p 142.

${ }^{116}$ See L Hoyano 'The Flight to the Fiduciary Haven' in P Birks (ed) Privacy and Loyalty (Oxford: Clarendon 1997) p 182 and Rotman, above $n$ 157, pp 143-145.

117 [1999] 1 All ER 400.

${ }^{118}$ Confirmed by Lord Millet in Dubai Aluminium Co Ltd v Salaam [2003] 2 AC 366, at 404.
} 
directors in the second 'accessory' category on the basis that their influence is indirect, since shadow directors are not necessarily dealing directly with the company's assets. ${ }^{119}$ So the decision in Ultraframe finds that being a 'shadow director' is not a relevant relationship for the purposes of imposing fiduciary duties, as it not a 'relationship of trust and confidence', since a shadow director does not have any direct legal power or control over the property of the company.

Whilst fiduciary relationships have been justified on property grounds, ${ }^{120}$ such justifications are simply not adequate when considering fiduciary duties generally, and are even more problematic when considering the difficult case of the shadow director. Fiduciary relationships may concern the exercise of power over property, but particularly in the case of the company director the fiduciary duties to the company extend far beyond the handling of the company's tangible property, to include issues such as promoting the success of the company, acting within powers, avoidance of conflicts of interest and the exercise of independent judgment amongst other requirements. ${ }^{121}$ Furthermore, Lewison J's property-based justificatory approach appears even more dubious given that de jure directors, particularly of the non-executive type, may also never deal directly with the assets of the company, yet will still owe fiduciary duties to the company. Nevertheless, after Ultraframe, shadow directors were at best dishonest assistants rather than fiduciaries, which has a number of significant implications for those bringing claims against shadow directors on behalf of the company. Not only

\footnotetext{
${ }^{119}$ At para 1289, Lewison J did suggest that shadow directors may have limited fiduciary duties to the company due to particular actions that they undertake, but relied on the words of Rimer J in Brinks Ltd v Abu-Saleh (no 3) [1999] CLC 133 at 148, to suggest that this would not mean the full range of directors' fiduciary duties were then automatically owed.

${ }^{120}$ See Miller (2013), above n 20, pp 987-989. See also L Ribstein 'Are Partners Fiduciaries?' [2005] 1 U III L Rev 209 at 212 for a key example of a property-based justification.

${ }^{121}$ For a general criticism of using property theory as a justification for fiduciary relationships, see Miller (2013), above $\mathrm{n} 20, \mathrm{p}$ 989. For an alternative 'critical resource theory' see D Smith 'The Critical Resource Theory of Fiduciary Duty' (2002) 55(5) Vand L Rev 1399 and the corresponding criticism by Miller (2013), above n 20, pp 989-991. See also Rotman, above $n$ 15774, pp 86-93. There is, however, a question as to whether some of these directors' duties should be considered as fiduciary in nature. Robert Flannigan has argued that only the directors' duties designed to control opportunism by errant directors should be classified as fiduciary, on the basis that the other duties require evidence of blameworthiness rather than liability being imposed on a strict liability basis. See R Flannigan, 'The adulteration of fiduciary doctrine in corporate law' (2006) 122 LQR 449.
} 
was shadow director liability dependent on overcoming an additional barrier in the form of a test of dishonesty, ${ }^{122}$ but the remedies that were likely to be available were far more restricted, ${ }^{123}$ for example in relation to the availability of proprietary remedies, and therefore priority over non-secured creditors, in the event of bankruptcy of the shadow director concerned. ${ }^{124}$ There are also doubts generally about the application of 'dishonest assistant' principles to those assisting a company director, ${ }^{125}$ and it is also a concern, once again, that a controlling shadow director would have a lesser degree of liability compared to those de jure directors under her practical controlling influence. ${ }^{126}$

\section{THE REFORMULATED UNDERTAKING TEST}

Finn himself subsequently suggested that the original formulation of 'undertaking' test itself was unhelpful, as noted above, given that fiduciary duties are in reality imposed rather than being accepted. The point Finn made is that what whilst it is important to recognise what the alleged fiduciary has agreed too, public policy considerations will define the breadth and depth of the fiduciary obligations owed to the principle. Consequently, Finn ventured to offer the following reformulation, both in his academic work, and in his subsequent judicial decisions,

\footnotetext{
${ }^{122}$ The requirement of dishonesty for accessories was established in Royal Brunei Airlines Sdn Bhd $v$ Tan [1995] 2 AC 378 at 389 (Lord Nicholls). For subsequent controversy over the correct formulation of the test see Twinsectra v Yardley [2002] 2 AC 164; Barlow Clowes International Ltd v Eurotrust Ltd [2005] UKPC 37; AbouRahman [2006] EWCA Civ 1492 and Moffat, above n 177, pp 762-764. See generally E Hadjinestoros, 'Stigmata of fiduciary duties in shadow directorship' (2012) 33(11) Comp Law 331.

${ }^{123}$ Although the recent Court of Appeal decision in Novoship (UK) Ltd v Mikhaylyuk [2014] EWCA Civ 908 did allow the equitable account of profits remedy to be applied to a dishonest assistant.

${ }^{124}$ For a general discussion of this issue see McGhee, above n 9, para 26-004 and Moffat, above n 177, pp 742 -769 .

${ }^{125}$ The principles were successfully applied in Baden v Société Generale [1993] 1 WLR 509 at 573, but not in Ultraframe itself, and have been doubted or left open elsewhere see Goose $v$ Wilson Sandford \& Co [2001] Lloyd's Rep PN189 and Gencor ACP Ltd v Dalby [2000] 2 BCLC 734 at 757. See generally McGhee, above n 9, paras 30-076 to 30-087.

${ }^{126}$ See generally Moore, above $\mathrm{n} 11$.
} 
'a person will be in a fiduciary in his relationship with another when and insofar as that other is entitled to expect that he will act in that other's or in their joint interest to the exclusion of his own several interest. $^{127}$

The theoretical status of Finn's reformulation is controversial. Edelman argues that Finn's reformulation becomes part of the 'undertaking test', with the analysis of 'legitimate expectations' taking place by implication or expression in order to define the nature of fiduciary duties which have been undertaken. ${ }^{128}$ If this reformulation is part of the 'undertaking test', then the majority of the criticisms regarding Edelman's theory continue to apply. Alternatively, the reformulation could be described as a justification based on reliance, which unfortunately suffers from similar problems to those justifications based on loyalty, ${ }^{129}$ and therefore also fails to provide an adequate justification. However, Finn's maintains that the fiduciary principle is an instrument of public policy, deployed 'to maintain the integrity, credibility and utility of relationships perceived to be of importance in society,' as well as protecting personal and economic interests. ${ }^{130}$ The problem is that, as Miller identifies, whilst Finn emphasises the public importance of certain fiduciary relationships, he still provides no clear policy justification for fiduciary duties in general. ${ }^{131}$ In any case, regardless of which of these theoretical approaches is deployed, all accept that fiduciary duties can be imposed constructively by the courts beyond those originally objectively agreed between the parties, ${ }^{132}$ but unfortunately no clear guidance is provided by the reformulation as to when such an imposition of fiduciary duties should occur. Consequently, whilst the reformulation potentially widens the categories of potential fiduciaries, a complete definition of the fiduciary relationship is still absent.

\footnotetext{
${ }^{127}$ P Finn 'The Fiduciary Principle' in Youdan (ed) Equity, Fiduciaries and Trusts (Toronto: Carswell, 1989) p 54; P Finn, 'Fiduciary Law' in E McKendrick (ed) Commercial Aspects of Trusts and Fiduciary Obligations (Oxford: Clarendon Press, 1992) p 9 and as Finn J in Grimaldi v Chameleon Mining NL (No.2) [2012] FCAFC 6 at para 177. ${ }^{128}$ Edelman, above $n$ 184, at 318.

${ }^{129}$ See J Shepherd 'Towards a Unified Concept of Fiduciary Relationships' (1981) 97 LQR 51, at 58-59.

${ }^{130}$ Finn (1989), above n 212, p 26.

131 See Miller (2013), above n 20, p 1001.

132 Edelman, above n 184, p 327, does accept that fiduciary duties will be imposed in certain circumstances.
} 


\section{APPLICATION OF THE REFORMULATED ‘UNDERTAKING’ TEST IN VIVENDI V RICHARDS}

Finn's later reformulation was recognised in the Privy Council case of Arklow Investments v Maclean, ${ }^{133}$ but has not been universally applied by English judges, and was not applied in Ultraframe, despite longstanding approval from the venerable Snell's Equity. ${ }^{134}$ However, Finn's reformulation was applied to shadow directors in the recent High Court decision in Vivendi SA v Richards, which saw a reevaluation of a number of key issues in relation to the previously discussed case law. ${ }^{135}$ Firstly, Newey $\mathrm{J}$ identified that there was more support for the position taken in Yukong Line then had been acknowledged in Ultraframe, namely from the Law Commission in a 1998 consultation paper ${ }^{136}$ and in the unreported High Court case of John v Price Waterhouse. ${ }^{137}$ Secondly, he identified that Ultraframe had received much academic criticism on the basis that it was 'odd' that the full range of directors' fiduciary duties were not owed, ${ }^{138}$ and that it was 'unfortunate' that the true mover of the company was able to easily distance themselves from liability for the decisions taken. ${ }^{139}$ In the case itself, Newey $\mathrm{J}$ focussed on establishing the existence of a fiduciary relationship by finding an undertaking or assumption of responsibility. He advanced a number of other authorities in support of the undertaking

\footnotetext{
133 [2000] 1 WLR 594 at 598 (per Henry J).

${ }^{134}$ For example see the current Snell's Equity (McGhee, above $n$ 9, para 7-005).

135 The key part of the judgement is paras 133 to 145.

${ }^{136}$ As Newey J (para 134) identified, the assertion that a shadow director could be regarded as akin to a de facto directors for the purpose of the directors' general duties, was made in Law Commission Consultation Paper, Company Directors: Regulating Conflicts of Interests and Formulating a Statement of Duties (Law Com. No.153, 1998) (at para 17.15). Indeed this view was supported by the majority of the respondents and was subsequently echoed in the Company Law Review (Modern Company law for a Competitive Economy: Completing the Structure. URN 00/1335 (2000) at para 4.7). However, the white paper, Company Law Reform (Cm 6456, March 2005) (at para 3.3) made it clear that some duties would apply differently to shadow directors. See Moore, above $\mathrm{n} 11, \mathrm{p} 2$ and the discussion regarding shadow directors above.

${ }^{137}$ Unreported, High Court, 11 April 2001, WL 273028.

${ }^{138}$ D Prentice and J Payne 'Case Comment: Directors' Fiduciary Duties' (2006) 122 LQR 558, at 562 as endorsed by D Kershaw Company Law in Context (Oxford: OUP, 2nd edn, 2012) p 330. Newey J's comment is at para 136. ${ }^{139}$ Davies and Worthington, above $\mathrm{n} 13, \mathrm{pp}$ 512-513.
} 
test, including the opinions of Finn, ${ }^{140}$ Edelman, ${ }^{141}$ as well as Australian ${ }^{142}$ and English case law. ${ }^{143}$ Ultimately, he combined these opinions to identify two basic features of the 'undertaking' test,

'first, the question whether there was such an undertaking/assumption must be determined on an objective basis rather than by reference to what the alleged fiduciary subjectively intended; secondly, the taking on of a role or position must be capable of implying an undertaking/assumption of responsibility'144

He further concluded that an individual cannot escape fiduciary duties simply because he did not want to assume them, or because nobody would expect him to assume them because he was known as a dishonest person, the duties instead arising solely on the assumption of the relevant position. ${ }^{145}$

However, despite using this 'assumption of responsibility' based formulation, ${ }^{146}$ Newey J still faced the same key difficulty that Lewison J faced in the Ultraframe case, namely whether the position of shadow director was a 'relevant position' for purposes of the above test. ${ }^{147}$ So once again the 'undertaking' test alone failed to provide a complete justification for fiduciary duties, even in this alternative 'assumption of responsibility' format. Newey $J$ in fact answered this second question primarily by making analogies between shadow directors and other established fiduciary relationships, with the crucial comparisons being with the fiduciary duties of both de facto directors

\footnotetext{
${ }^{140}$ Finn (1989), above n 127, p 54.

${ }^{141}$ Edelman, above $\mathrm{n} 184, \mathrm{p} 317$.

142 Hospital Products Ltd $v$ United States Surgical Corp (1984) 156 CLR 41 at p 97-98 (per Mason J).

${ }^{143}$ F \& C Alternative Investments (Holdings) Ltd v Barthelemy (No.2) [2011] EWHC 1731, [2012] Ch 613 at para 225 (per Sales J), and Ross River Ltd v Waveley Commercial Ltd [2012] EWHC 81 (Ch) at para 256 (per Morgan J). 144 [2013] EWHC 3006 (Ch) at para 139.

${ }^{145}$ At para 139.

${ }^{146}$ Citing White v Jones at 271 (per Lord Brown-Wilkinson).

147 [2013] EWHC 3006 (Ch) at paras 139-145.
} 
and promoters, ${ }^{148}$ although he also suggested that public policy also probably pointed to this outcome. ${ }^{149}$ Such use of analogical reasoning raises two main concerns: firstly, whether such a comparison between shadow directors and de facto directors, or indeed promoters, is strictly accurate and, secondly, whether the making of such analogies really offers a sufficiently sound theoretical foundation for the assertion that shadow directors should be fiduciaries.

A first glance making analogies between shadow directors and de facto appears to be attractive, given that both categories share a lack of formal appointment. However, as discussed above, the approach taken in the Companies Act seems to negate such a comparison, given that de facto directors and de jure have are equated, ${ }^{150}$ while shadow director liability has developed on a far more ad hoc basis. However, beyond the statutory definitions of the concepts, clear evidence of convergence can be found in the case law, particularly as the definition and application of the de facto director concept has evolved. Whilst originally the de facto directors cases concerned individuals who had previously been de jure directors of the company, or whose appointment was defective or deficient in some way, from the 1980s onwards de facto directorship began to be ascribed to individuals who had never been appointed or purportedly appointed as directors of the relevant company. ${ }^{151}$ Most of the recent case law has centred on the classic definition of de facto director supplied by Millet J (as he then was) in Re: Hydrodam, ${ }^{152}$

\footnotetext{
${ }^{148}$ At para 142.

${ }^{149}$ The public policy justification is not explored by Newey J, but see academic criticism by Miller (2013), above n 20, pp $1000-1001$.

${ }^{150}$ CA 2006, s 250 .

${ }^{151}$ See the account of Lord Collins in Holland v Revenue \& Customs Commissioners [2010] UKSC 51, [2010] 1 WLR 2793 at para. 73-81. Lord Collins also suggested that the only case that foreshadowed the modern development of the law in relation to de facto directors was re Western Counties Steam Bakeries and Milling Co [1897] 1 Ch 617.

${ }^{152}$ Re Hydrodam (Corby) Ltd [1994] BCC 161.
} 
'a person who assumes to act as a director. He is held out as a director by the company, claims and purports to be a director, although never actually or validly appointed as such. To establish that a person was a de facto director of a company it is necessary to plead and prove that he undertook functions in relation to the company which could probably be discharged only by a director.' ${ }^{153}$

A long line of cases have then attempted to derive a test from Millet J's statement, ${ }^{154}$ culminating in the Supreme Court decision in Holland v Revenue \& Customs Commissioners, ${ }^{155}$ in which all judges (whether in the majority or dissenting) found that the question to be asked in most cases was whether the person concerned was 'part of the corporate governing structure' or 'assumed the duties of a director' rather than whether or not the individual concerned held themselves out to as a director. ${ }^{156}$ The point is that an individual assumes the role of de facto director not because they have held themselves out to be a director, nor because they have been purportedly appointed as a director or given such a designation, ${ }^{157}$ but because of the role undertaken within the corporate governance structure. ${ }^{158}$

\footnotetext{
153 [1994] BCC 161 at 163.

${ }^{154}$ For example see: re Richborough Furniture Ltd [1996] 1 BCLC 507, Secretary of State for Trade and Industry $v$ Tjolle [1998] 1 BCLC 333, Re Kaytech International plc [1999] 2 BCLC 351, Secretary of State for Trade and Industry $\checkmark$ Hollier [2007] Bus LR 35, re Mea Corpn Ltd [2007] 1 BCLC 618, Secretary of State for Trade and Industry v Hall [2009] BCC 190, See also the earlier cases of re Lo-Line Electric Motors Ltd [1988] Ch 477.

155 [2010] UKSC 51, [2010] 1 WLR 2793.

156 See Lord Hope at [39], Lord Collins at [93-94]; Lord Walker [108-111].

157 S.250 CA 2006.

158 Secretary of State for Trade and Industry v Tjolle [1998] 1 BCLC 333 where Jacob J cited a passage from Cooke $\mathrm{J}$ in Secretary of State for Trade and Industry v Elms (unreported 16 January 1997); This definition of a defacto director was confirmed in Ultraframe (UK) Ltd v Fielding [2005] EWHC 1638 (Ch).
} 
Given that a representation regarding the role being undertaken is no longer a necessary step in identifying a de facto director, and, as identified above, Deverell makes it clear that a shadow director need not lurk in the shadows, ${ }^{159}$ it would appear that the de facto and shadow director concepts are similar, despite the fact that Millett J suggested Re: Hydrodam that it was 'embarrassing' not to differentiate between the two concepts. ${ }^{160}$ Lord Collins concludes in Holland ${ }^{161}$ that the distinction made by Millett was impossible to maintain, given the wider definition of de facto director that has subsequently been deployed, ${ }^{162}$ with the latest version of Gower \& Davies also arguing that the two concepts share more in terms of commonality then they do difference and that both the fiduciary and non-fiduciary directors' duties ought to apply to shadow directors. ${ }^{163}$ Nevertheless, differences do remain since de facto directors carrying out the role of director personally, with direct legal powers, whereas the shadow director provides instructions for other directors to follow and so wields practical influence rather than any direct legal power. However, practically speaking, the shadow director is more potentially more powerful, given that de facto directors are simply acting as one individual director, meaning that they may be potentially out-voted by other directors, while shadow directors, by definition, must possess control of the majority of the board of directors. Overall the making of such an analogy between the shadow director and de facto director concept is uncomfortable, and potentially dubious, given these clear, and potentially material,

\footnotetext{
${ }^{159}$ Lord Walker confirmed this point in obiter in Holland at [2010] UKSC 51, [2010] 1 WLR 2793 at para 109. He suggested that Millett J recognised this himself, given the example he gave in a later paragraph in re Hydrodam [1994] BCC 161, 164. He also referred to similar statements by himself in the Court of Appeal case of re Kaytech International plc [1999] BCC 390 at 402 and by Morritt $\mathrm{L}$ in Secretary of State for Trade and Industry v Deverell [2001] Ch 340 at para 36.

${ }^{160}$ Millet J's reasoning for making this statement was that a de facto director assumes to act as a director and is held out by the company to be a director despite his or her lack of appointment, while a shadow director claims not to be a director and 'lurks in the shadows' (Re Hydrodam (Corby) Ltd [1994] BCC 161 at 163).

161 [2010] UKSC 51, [2010] 1 WLR 2793 at para 91.

162 Also in Holland, Lord Walker, at para 110, agreed with the view of Lewison J in re Mea [2007] BCC 288, para 89 that an individual could be a de facto and shadow director simultaneously.

${ }^{163}$ Davies and Worthington, above $n 13, p 514$.
} 
differences between the two concepts. The comparison between shadow directors and promoters also raises similar concerns, the difficulty being that once again promoters, unlike shadow directors, wield direct influence rather than indirect influence on the company. This problem is also further compounded by the fact, as Gower and Davies emphasises, that the promoter role has never been clearly defined judicially or legislatively and therefore is essentially an ambiguous concept. ${ }^{164}$

The second issue is, as identified above, that using analogy as a justificatory theoretical tool is potentially problematic generally, despite the classical importance of analogical reasoning to the common law when extending or distinguishing precedent judgments. ${ }^{165}$ The danger is that a relevant analogical fiduciary relationship will be found when there is a 'perceived need' to identify a relationship as fiduciary, yet often there is a lack of clear principles guiding the analogical approach. ${ }^{166}$ For example, DeMott argues that while analogies may be useful, they should not be substitutes for analytical reasoning, as results maybe be confusing and ineffective, ${ }^{167}$ while Birks warns that there is a danger that serious mistakes may be made. ${ }^{168}$ However, the general position in relation to the use of analogies is more complex, as Grant Lemond has recently identified, ${ }^{169}$ since some theorists do see

\footnotetext{
164 See Davies and Worthington, above n 13, p 112. Although, as Gower \& Davies (ibid) emphasises, a number of judicial attempts have been made, see: Twycross v Grant (1877) 2 CPD 469 at 541 (per Cockburn CJ), Emma Silver Mining Co v Lewis (1879) 4 CPD 469 at 541 (per Lindley J) and Whaley Bridge Printing Co v Green (1880) 5 QBD 109 at 111.

${ }^{165}$ See G Postema 'A Similibus ad Similia: Analogical Thinking in Law' in DE Edlin (ed) Common Law Theory (Cambridge: CUP, 2007) pp 102-104. Postema identifies that the importance of analogy to common law reasoning was identified as early as the $13^{\text {th }}$ century in the writing of Henry de Bracton. On legal reasoning by analogy generally see: G Postema The Problems of Jurisprudence (Cambridge, Mass: Harvard University Press, 1990) pp 86-98.

${ }^{166}$ See Rotman, above n 157, pp 74-75.

167 D DeMott 'Beyond Metaphor' (1988) Duke LJ 879, pp 923-24; Rotman, above n 157, pp 74-75.

168 Birks, above $n$ 89, p 23. See Rotman, above $n$ 747, p 75.

${ }^{169}$ See Grant Lamond 'Analogical Reasoning in the Common Law' (2014) 34 Oxford Journal of Legal Studies 567, pp $567-568$.
} 
analogies as pivotal to common law reasoning, ${ }^{170}$ while others see analogies as being without normative force, ${ }^{171}$ or owing their normative force to an independent element, such as principles ${ }^{172}$ or their rationale. ${ }^{173}$ He suggests that all of these views have merit, but argues that part of the explanation for the dispute over the use of analogical reasoning in common law arises because the analogy is used in three distinct ways: classificatory analogies, close analogies, and distant analogies. Classificatory analogies are used to perform a legal characterisation of the facts of the case, close analogies resolve unsettled issues by reliance on decisions from other instances of the same legal doctrine, while distant analogies resolve issues by reference to decisions made in relation to other legal doctrines. Generally speaking, Lemond argues that whilst the first two categories of analogy are important to the process of legal reasoning, distant analogies are more susceptible to critique and should be used sparingly. ${ }^{174}$

Given that the analogical justification of fiduciary duties for shadow directors seems to be based upon classificatory and close analogies, it would seem at least arguable that the reasoning of Newey $\mathrm{J}$ in Vivendi is a reasonable approach to justifying shadow director fiduciary duties. The analogies deployed here are classificatory in the sense that they compare de facto directors and promoters to shadow directors, and find these categories sufficiently similar to justify the shadow - director company relationship as fiduciary. The analogy with de facto directors is also close in the sense that a doctrinal rule from one sub-set of the company director doctrine (de facto directors), is also being applied to a

\footnotetext{
${ }^{170}$ Lamond, ibid, p 567, cites EH Levi An Introduction to Legal Reasoning (Chicago: University of Chicago Press 1948) pp 1-3; and L Weinreb Legal Reason: The Use of Analogy in Legal Argument (Cambridge: CUP 2005) pp 15 , as examples of this view.

${ }^{171}$ Lamond, ibid, pp 567-568, places RA Posner How Judges Think (Cambridge, Mass: Harvard University Press, 2008) 180-91; and L Alexander and E Sherwin Demystifying Legal Reasoning (Cambridge: CUP, 2008) Ch 3, in this category.

${ }^{172}$ Lamond, ibid, p 568, suggests N MacCormick Legal Reasoning and Legal Theory (Oxford: OUP 1978) Ch 7 and RM Dworkin, 'In Praise of Theory' (1997) 29 Arizona State LJ 353, both fit this description.

${ }^{173}$ Lamond, ibid, p 568, suggests J Raz, 'Law and Value in Adjudication' in The Authority of Law (Oxford: OUP, $2^{\text {nd }}$ edn, 2009); and S Brewer, 'Exemplary Reasoning: Semantics, Pragmatics, and the Rational Force of Legal Argument by Analogy' (1996) 109 Harv L Rev 923, are both examples of this latter view.

${ }^{174}$ Lamond, ibid, pp 583-584.
} 
different sub-set (shadow directors). ${ }^{175}$ So potentially, applying Lamond's scheme at least, making analogies with de facto directors and promoters will potentially provide a justification for fiduciary duties for shadow directors. However, in reality the main problem with using such as an analogy under these circumstances is not analogical reasoning per se, but in a related issue identified by Lamond: namely that successful use of analogy is predicated 'upon legal doctrines having rationales that make sense of their existence and content. ${ }^{\prime 176}$ In other words a clear rationale is needed to denote why a de facto director or a promoter is a fiduciary, which, as discussed above, seems to be absent from the relevant case law. It is tempting to conclude that shadow directors ought to owe fiduciary duties to the company because promoters and de facto directors have such duties, as Newey J does at least in part, but to pursue such an analogy leaves the question of why shadow director should be fiduciaries substantially unanswered.

The decision by Newey $\mathrm{J}$ in Vivendi is arguably a step in the right direction in that shadow directors are found to be fiduciaries in relation to instructions or directions given to shadow directors, as well as owing general fiduciary duties of good faith and loyalty to the company when giving such instructions, ${ }^{177}$ but unfortunately theoretical and practical difficulties still remain. The 'undertaking' test alone was still insufficient to conclusively identify fiduciary obligations, which is perhaps unsurprising given that even Edelman has subsequently suggested that an objective undertaking is a necessary yet not sufficient basis for imposing fiduciary duties. ${ }^{178}$ Furthermore, supplementing the undertaking test with an analogical approach, as happened in Vivendi, seems just a problematic as using the property-based justification deployed in Ultraframe. Whilst a number of the other potential justifications, both reductivist and instrumentalist, could be applied by the courts to the shadow

\footnotetext{
${ }^{175}$ Arguably the analogy with promoters is a distant analogy, given that such individuals appear to be doctrinally separate from the company director concept.

${ }^{176}$ Lamond, above $\mathrm{n} 268$, p 569.

177 [2013] BCC 771 at 143.

${ }^{178}$ Edelman, above n 172, p 128.
} 
director question, criticism of these justifications, discussed above, suggest that they too would have limitations.

\section{THE ‘POWER AND DISCRETION’ TEST}

The proposal is that a better theoretical basis for identifying shadow directors as fiduciaries could be achieved by introducing the Canadian 'power and discretion test' into English law, given that it better illuminates the essential elements of a relationship that compels the imposition of fiduciary duties, ${ }^{179}$ as well as having a strong theoretical justification via Paul Miller's 'fiduciary powers theory'. ${ }^{180}$ Miller argues that a fiduciary relationship is a distinctive and coherent type of legal relationship that can be defined as, 'one in which one party (the fiduciary) exercises discretionary power over the significant practical interests of another (the beneficiary). ${ }^{181}$ In dissecting this definition, Miller identified definitive properties which delimit the types of relationship identified by the definition, and structural properties which identify implications of a particular relationship for the parties concerned. ${ }^{182}$

According to Miller, the key definitive property of fiduciary relationships is power, although of course, as Miller recognises, power is it itself conceptually ambiguous. ${ }^{183}$ Miller firstly rejects Hohfeld's general definition of legal power, which defines legal power as 'capacities (devised or sanctioned by law) to alter the legal position or relationship of another', ${ }^{184}$ on the basis that is inadequate for describing the power that fiduciaries have. ${ }^{185}$ Instead, Miller proceeds to identify a new fiduciary form of power.

\footnotetext{
${ }^{179}$ For arguments that such essential characteristics of the fiduciary relationship cannot be defined see Demott, above n 167, pp 934-5 and Glover, above n 84, at p 275. See Miller (2013), above n 20, p 1010 for a counterargument.

${ }^{180}$ For a full justification of his juridical approach see Miller (2013), above n 20, pp 1007-1015.

${ }^{181}$ Miller (2014), above n 20, pp 73.

182 Miller (2014), above n 20, pp 69.

${ }^{183}$ See Miller (2014), above n 20, pp 69-71 and Shepherd, above n 157, pp 83-88.

${ }^{184}$ See W Hohfield 'Some Fundamental Legal Conceptions as Applied in Judicial Reasoning' (1913) 23 Yale LJ 16.

${ }^{185}$ As Miller notes, some fiduciaries wield powers over the material rather than legal interests of the principle, such as a parent, consequently the legal position of the principal might well not be affected. Conversely, other
} 
According to Miller, 'fiduciary power' is unique by virtue of the fact that the fiduciary acts as a substitute in exercising a legal capacity, which derives from the principal's legal personality. ${ }^{186}$ Miller explains that the fiduciary is in fact, by the power vested in here, standing in substitution for the principal. Miller also argues that due to its source, fiduciary power is expressly devoted to serving the practical interests of the other, which represents another key definitive property of the 'fiduciary powers theory'. ${ }^{187}$ Beyond this, Miller identifies the three structural properties of this theory as inequality, dependence and vulnerability. Inequality typifies fiduciary relations due to unequal levels of fiduciary power within the relationship, which exists independently of 'any circumstantial inequality' that might exist between the parties. So the principal is always subordinate within the fiduciary relationship, despite being potentially ascendant in every other aspect. Both dependence and vulnerability are, according to Miller, reflective of the 'structural inequality generated by the formation of a fiduciary relationship'. ${ }^{188}$

As Miller emphasises, company directors are the quintessential fiduciary given their unusually broad powers are, clearly, 'in the nature of authority derived from the legal capacity of another person or group of persons' and therefore fit strongly within his definition of fiduciary power. ${ }^{189}$ The far more difficult question is whether or not shadow directors can also be included within Miller's definition of fiduciary power, and therefore be fiduciary, given that shadow directors are influencing other directors to exercise their power in a particular manner, rather than exercising any legal power directly themselves. This of course locates the shadow director - company relationship as a 'hard case', particularly as under Miller's definition of fiduciary power, as Miller himself identifies, advisers will

\footnotetext{
individuals wield legal power in the manner Hohfeld describes in non-fiduciary situations, for example in contractual situations. See Miller (2014), above $n$ 20, p 70 for more on this.

${ }^{186}$ Miller (2014), above $\mathrm{n} 20$, pp 70-72. Such a definition overcomes a number of previous criticisms of 'power and discretion' theories, see Rotman, above $\mathrm{n} 747$, pp 147-148

${ }^{187}$ Miller (2014), above n 20, pp 71-72.

188 Miller (2014), above $n$ 20, p 73.

${ }^{189}$ See generally Miller (2014), above $n$ 20, pp 80-82.
} 
not normally be fiduciaries. ${ }^{190}$ However, as identified repeatedly above, an individual only becomes a shadow director when the de facto and de jure directors are accustomed to act on the instructions given by the individual concerned and this difference is crucial for the application of the fiduciary powers theory to shadow directors. Citing the statements of Justice Mclachlin in the Canadian case of Hodgkinson with approval, ${ }^{191}$ Miller explains that the crucial distinction is that advisors become fiduciaries usually not because of the advice they give, but instead only where they 'exercise discretionary power over the practical interests of their clients' ${ }^{192}$ However, he does acknowledge that where the advisee is no longer capable of exercising independent judgement, the advisor has effective discretionary power over the advisee, despite the lack of a formal cessation of capacity by the advisee, and therefore will be a fiduciary. ${ }^{193}$ It is submitted that, given that 'effective discretionary power' is sufficient for the finding of discretionary fiduciary power according to Miller, shadow directors will clearly be fiduciaries under the fiduciary powers theory, by virtue of the level of influence and indirect control exercised by the shadow director in relation to the board of directors.

Whilst Miller provides a theoretical basis for identifying fiduciary relationships, it is necessary to consider how such elements can be formulated as a practical test, which can then be applied to shadow directors. In the Canadian Supreme Court case of Frame v Smith, ${ }^{194}$ Wilson J identified three general characteristics of fiduciary relationships that have come to be known as the "power and discretion' test. Whilst a number of justifications for these elements have been proposed by the Canadian courts, which fall foul of many of the criticisms described above, ${ }^{195}$ the 'power and

\footnotetext{
190 See Miller (2014), above n 20, pp 83-84.

191 [1994] 3 SCR 377 (SCC) at 466.

192 Miller (2014), above n 20, pp 84.

193 Miller (2014), above n 20, pp 84, fn 76.

194 (1987) 42 DLR (4th) 81.

195 For example Forrest J in Hodgkinson v Simms (1994) 117 DLR (4th) 161 at paras 45-52, uses both public policy and morality considerations. See Rotman, above n 170, pp 965-969.
} 
discretion' test nevertheless offers a clear practical approach to the implementation of Miller's theory.

The elements from Frame $v$ Smith are,

'(1) The fiduciary has scope for the exercise of some discretion or power.

(2) The fiduciary can unilaterally exercise that power or discretion so as to affect the beneficiary's legal or practical interests.

(3) The beneficiary is peculiarly vulnerable to or at the mercy of the fiduciary holding the discretion or power.' $^{196}$

Subsequently these three characteristics have become the established method for identifying fiduciary relationships in both Canada and New Zealand, and have even been applied at least once by the Court of Appeal in England. ${ }^{197}$ The three characteristics will be considered in turn, both in relation to Canadian Supreme Court jurisprudence generally and in terms of a potential application to shadow directors in English law.

In relation to the first requirement, that the fiduciary must have scope for the exercise of some discretion or power, it is immediately obvious that power is vital characteristic as Miller has emphasised. Without the ability to exercise such power, as Wilson J emphasised in Frame $v$ Smith, ${ }^{198}$ there is no need to restrict the individual concerned by the imposition of fiduciary obligations. Of

196 (1987) 42 DLR (4th) 81 at para 39-42.

197 This test has been approved by LAC Minerals Ltd $v$ International Corona Resources Ltd [1989] 61 DLR (4th) 14, (per Sopinka and La Forest JJ), Canson Enterprise Ltd v Boughton \& Co [1992] 85 DLR (4th) 129. (per McLachlin J, Lamer CJC and L'Heureux-Dubé J) and Norberg $v$ Wynrib [1992] 92 DLR (4 $\left.{ }^{\text {th }}\right) 449$ at para 70 (per La Forest J, with Gonthier J and Cory J concurring), amongst others in Canada. See DHL International (NZ) Ltd v Richmond Ltd [1993] 3 NZLR 10 at 22, CA in New Zealand, and Goose v Wilson Sandford \& Co (No.2) [2001] Lloyd's Rep PN189 in England.

198 (1987) 42 DLR (4th) 81 at para 43. 
course the possession of such power is not a wrong in itself, ${ }^{199}$ as the fiduciary will require such power to function as a substitute for the principal, but crucially it must only be used for the given purpose..$^{200}$ In terms of application of this principle to shadow directors, as identified above, in relation to the discussion of Miller's fiduciary powers theory, even if we confine the definition of fiduciary power to that proposed by Miller, shadow directors possess 'effective discretionary power' over the board of directors and therefore shadow directors have the requisite scope for the exercise of some discretion or power.

The second requirement, that 'a fiduciary can unilaterally exercise that power or discretion so as to affect the beneficiary's legal or practical interests', is also important. ${ }^{201}$ Without leeway or discretion, as Weinrib states, 'there is nothing on which the fiduciary obligation can bite', ${ }^{202}$ but the danger is that the power will be misused to injure the principal rather than benefitting him. ${ }^{203}$ The phrase 'legal or practical interests' is also crucial, since it allows fiduciary obligations to extended beyond mere financial or property interests, and emphasises that, for example, company directors' duties extend to other interests such as the general financial wellbeing of the corporation, and possibly to intangible interests such as the corporations' public image and reputation. ${ }^{204}$ Given that a shadow director has fiduciary power, at least according to Miller's definition, then, practically speaking, the shadow director can affect the legal and/or practical interests of the company.

\footnotetext{
${ }^{199}$ See Norberg $v$ Wynrib [1992] 92 DLR $\left(4^{\text {th }}\right) 449$ at para 72 (per McLachlin J). The judge also referred Frankel, above $\mathrm{n} 168, \mathrm{p} 809$, who stated that 'the fiduciary must be entrusted with power in order to perform his function'.

${ }^{200}$ See Frankel, above n 858, pp 808-809.

${ }^{201}$ E Weinrib 'The Fiduciary Obligation' (1975) 25 UTL 1. p7, describes this requirement as the hallmark of a fiduciary relationship, this is also approved by Dickson J in Guerin $v R$ [1985] 13 DLR (4th) 321.

${ }^{202}$ Weinrib, above $n$ 306, $p 7$.

${ }^{203}$ Frankel, above n 858, p 809.

${ }^{204}$ Frame v Smith (1987) 42 DLR (4th) 81 at para 44 (Wilson J).
} 
The third, and arguably the most important, requirement that the 'beneficiary is peculiarly vulnerable to or at the mercy of the fiduciary holding the discretion or power', is possibly the most difficult of the three principles to apply to shadow directors. Wilson J in Frame $v$ Smith defined vulnerability as 'the inability of the beneficiary (despite his or her best efforts) to prevent the injurious exercise of the power or discretion combined with the grave inadequacy or absence of other legal or practical remedies to re-dress the wrongful exercise of the discretion or power'. ${ }^{205}$ She also suggested that fiduciary obligations were seldom present in the dealings of experienced businessmen, since any vulnerability could have been prevented by a more prudent exercise of bargaining power ${ }^{206}$ However, fiduciary relationships, as Professor Weinrib ${ }^{207}$ and various Canadian judges have emphasised, ${ }^{208}$ should be assessed according to the position of the parties resulting from the agreement, rather than their relative positions prior to the agreement. So in fact the key question is whether the vulnerability arises from the relationship itself. ${ }^{209}$ In terms of assessing vulnerability, Frankel suggests that the level of risk of abuse of power, will depend upon the amount and extent of the power delegated to the fiduciary, along with the availability of protective mechanisms to reduce the likelihood of abuse. ${ }^{210}$ Given that the de jure directors have generally delegated significant amounts of power to the shadow director, and whilst the de jure director could intervene, the reality is that the company as a whole is highly vulnerable to the power wielded by the shadow director. Consequently this requirement, and indeed all other requirements of the 'power and discretion' test, are fulfilled, providing a strong indication that shadow directors ought to owe fiduciary duties.

\footnotetext{
${ }^{205}$ Frame v Smith (1987) 42 DLR (4th) 81 at para 45.

206 Ibid.

207 Weinrib, above $\mathrm{n}$ 306, p 6. Frankel, above $\mathrm{n} 168$, p 810 makes a similar point.

208 Perez v Galambos (2009) 312 DLR (4th) 220 at para 68 and Hodgkinson v Simms (1994) 117 DLR (4th) 161 at para 27.

${ }^{209}$ Perez v Galambos (2009) 312 DLR (4th) 220 at para. 67-68; Hodgkinson v Simms (1994) 117 DLR (4th) 161 at para 25-27 and Elder Advocates (2011) 331 DLR (4th) 257 at para 28. It has also been emphasised that describing the aim of fiduciary duties as the protection of the vulnerable alone is simply too broad. See Norberg $v$ Wynrib [1992] 92 DLR (4 $\left.{ }^{\text {th }}\right) 449$ at para 74; Perez v Galambos (2009) 312 DLR (4th) 220 at para 67; Hodgkinson v Simms at para 25-27 and Elder Advocates (2011) 331 DLR (4th) 257 at para 28.

${ }^{210}$ Frankel, above n 858, p 810.
} 


\section{A DUAL TEST FOR FIDUCIARY RELATIONSHIPS}

Although the 'power and discretion' test does help clearly identify fiduciary relationships, a number of criticisms have arisen of the test on the basis that many relationships protected by contract and negligence liability, also fulfil all of these characteristics. Such conflicts have been resolved by emphasising the strength of the vulnerability, ${ }^{211}$ or the requirement to identify 'total reliance', in fiduciary relationships, ${ }^{212}$ but it is submitted that such problems can be avoided by using the 'undertaking' test as well as the 'power and discretion' test. ${ }^{213}$ The undertaking requirement has also been recently reemphasised in Canada by McLachlin CJC in Elder Advocates of Alberta Society $v$ Alberta. ${ }^{214}$ The judge found that the 'power and discretion' test alone is not a complete code for the identification of fiduciary duties, ${ }^{215}$ and that an undertaking must be identified, ${ }^{216}$ alongside two other further requirements. ${ }^{217}$ Despite McLachlin CJC's perceived need for restatement in Elder Advocates, the undertaking requirement appears to have been present in Canadian fiduciary case law to a greater or lesser extent in the last 30 years, even with the general focus on the 'power and discretion' test. It can be identified in Frame $v$ Smith, when Wilson J refers approvingly to the speeches of Gibbs $\mathrm{CJ}$ and Mason J in the Australian case of Hospital Products Ltd. v. U.S. Surgical Corp. ${ }^{218}$ Additionally, as McLachlin CJC identifies, the undertaking requirement is explicitly stated by herself in Norberg $v$ Wynrib, ${ }^{219}$ La Forest J in Hodgkinson v Simms, ${ }^{220}$ and Cromwell J in Perez v Galambos. ${ }^{221}$ The test for finding an undertaking is discussed in some detail in this latter case. According to Cromwell $\mathrm{J}$ in Perez

\footnotetext{
${ }^{211}$ Frame v Smith (1987) 42 DLR (4th) 81 at para 45 (Wilson J).

212 Hodgkinson v Simms (1994) 117 DLR (4th) 161 at paras 132-133 (Sopinka J and McLachlin J).

${ }^{213}$ See generally Hoyano, above n 116, pp 178-189.

214 (2011) 331 DLR (4th) 257. See also P Maddaugh 'The Centrality of Undertaking in Identifying Fiduciary Relationships: Galambos v. Perez' (2011) 26 BFLR (Canada) 315, for a look at the earlier cases on this point.

${ }^{215}$ Elder Advocates of Alberta Society v Alberta (2011) 331 DLR (4th) 257 at para 29.

${ }^{216}$ At para 36.

217 At paras 33, 34-35 and 36. The two additional requirements are 'a defined person or class of persons vulnerable to a fiduciary's control' and a 'legal or substantial practical interest' likely to be effected by the principal's actions. Neither of these two requirements are likely to be problematic in the case of shadow directors.

218 (1984) 55 ALR 417. See Gibbs CJ at 432 and Mason J at 454.

${ }^{219}$ At para 98.

${ }^{220}$ At paras 33-34 (La Forrest J).

${ }^{221}$ (2009) 312 DLR (4th) 220 at paras 66 and 71.
} 
$v$ Galambos, Canadian law requires an undertaking by a fiduciary that may result from, 'statutory powers, the express or implied terms of an agreement or, perhaps simply an undertaking to act in this way.' He further suggested that the key question was whether there was some form of undertaking, whether express or implied, on the part of the fiduciary to act with loyalty. ${ }^{222}$ Having noted the academic support for such a requirement, ${ }^{223}$ Cromwell J identified that an express undertaking was not necessarily required, since the undertaking might 'be implied by the particular circumstances of the parties' relationship'. He suggested that relevant factors for establishing an implied undertaking should include 'professional norms, industry or other common practices', as well as whether the fiduciary induced the principal to rely on the fiduciary's loyalty. ${ }^{224}$

The 'power and discretion' test solves many of the difficulties from the English case law, since in conjunction with Miller's theoretical justification, it demonstrates why becoming a shadow director is a relevant position in terms of owing fiduciary duties to a company and explains why the shadow director - company relationship is one of trust and confidence. In other words, it answers the type of questions that the undertaking test, even when extended by Finn's wider reformulation, leave to judicial discretion via the application of an assorted range of other principles including, as discussed above, a range of reductivist, instrumentalist, or even analogical justifications. This confusion, and potential inconsistency, are resolved by the application of the 'power and discretion' test in the manner proposed. However, the presence of an undertaking, in its wider sense, remains important as the Canadian case law in the previous paragraph, and indeed Miller himself, ${ }^{225}$ recognises. Despite the fact that the 'undertaking' in shadow director cases is far from express, it is submitted that given the requirements to become a shadow director are expressly laid down in CA 2006, those who act in the

\footnotetext{
222 At para 77. Cited with approval by McLachlin CJC in Elder Advocates (2011) 331 DLR (4th) 257 at para 32. ${ }^{223}$ Scott, above $n$ 93, p 540; Finn, above $n$ 94, para 15 and more recently L Smith, 'Fiduciary relationships arising in commercial contexts - investment advisors' (1995) Can Bar Rev 714, at 717. 224 (2009) 312 DLR (4th) 220 at para 78-79. For a general discussion of undertaking in Canadian fiduciary law see Rotman, above $\mathrm{n} 74, \mathrm{pp} 93-100$. ${ }^{225}$ Miller (2014), above $n$ 20, p 74.
} 
manner prescribed have undertaken to be shadow directors and therefore accept the resulting legal consequences.

\section{CONCLUSION}

Shadow directors possesses massive influence in relation to the affairs of the company. They have practical power and control in one or more, or even all, areas of corporate management that, for whatever reason, the other de jure or de facto directors have been unable to resist. They can legitimately be described as the controllers of the company, with influence perhaps analogous to or even exceeding that of a de jure director, yet somehow doubts have pervaded English law about the fiduciary status of the relationship shadow director. This is largely due to the lack of a sufficiently principled basis for determining whether the company-shadow director relationship is fiduciary in nature, the lack of which is perhaps unsurprising given that genuine potential additions to the 'settled category' list of fiduciary relationships have arisen relatively rarely. It has been shown that whilst the 'undertaking' test alone can possibly be deployed successfully to demonstrate that shadow directors ought to have fiduciary duties to the company, the test itself is not a complete solution for identifying fiduciary relationships. Due to the incomplete nature of the 'undertaking' test, the courts have struggled to make consistent decisions about the fiduciary status of shadow directors, and this has not been aided by the deployment of a variety of different justifications for fiduciary duties and relationship. It has been argued here that such problems can be avoided in future by deploying the 'power and discretion' test alongside the 'undertaking' test.

While the proposed approach is somewhat more formulaic then the approach currently deployed by the courts, in that key elements of fiduciary relationships are clearly identified, nevertheless such an approach provides a clear justification for identifying shadow directors as fiduciaries, without realising Shepherd's fear that such a definition might damage the fiduciary concept, by robbing it 'of its 
dynamics and therefore its soul'. ${ }^{226}$ The proposed formulation offers a good balance between certainty of application and respect for the equitable nature of the fiduciary doctrine, ${ }^{227}$ and avoids both being too narrow, ${ }^{228}$ as well as avoiding excessive width, ${ }^{229}$ provided that Miller's definition of fiduciary power is deployed. A final question for consideration is whether the status-based method of identifying fiduciary relationships ought to be abolished. Edelman has strongly advocated the abolition of status-based fiduciary relationships, on the basis that better explanation of the reasons for the existence of fiduciary obligations is needed. ${ }^{230}$ Miller has also argued that using the status based approach leads to 'undisciplined analogical reasoning', ${ }^{231}$ and that a particular relationship may, 'enjoy merely notional membership in a legal category of which fiduciary power is a constitutive characteristic' ${ }^{232}$ In other words more accurate results are arguably achieved when each individual relationship is measured against the 'power and discretion' standard. While it is clear that the test proposed can justify fiduciary relationships in individual cases, it is submitted that such an approach is undesirable due to potential inconsistencies that would almost certainly arise as evidenced by the difficulties seen in Yukong, Ultraframe and Vivendi. Therefore, it is proposed that status-based fiduciary relationships remain, but ought to be justifiable via a dual 'undertaking' and 'power and discretion' test.

\footnotetext{
${ }^{226}$ Shepherd, above $\mathrm{n} 157, \mathrm{p} 3$.

${ }^{227}$ See generally Rotman, above $n$ 74, pp 6-7.

${ }^{228}$ For a discussion of the problems with establishing definitions in law, see Rotman, above $n$ 74, pp 79-80.

229 Obviously the 'power and discretion' test has been used to increase the categories of fiduciary relationship in Canada, for example to the doctor-patient in Norberg v Wynrib [1992] 92 DLR (4th) 449 (per McLachlin J) and also to personal and private relationships, such as parent and child in KM v HM; Women's Legal Education and Action Fund, Intervener (1992) 96 DLR $\left(4^{\text {th }}\right)$ 289. See Miller (2014), above $n$ 20, for a general discussion on where the dividing line should be placed. See also: P Finn, 'Equitable Doctrine and Discretion in Remedies' in W Cornish, R Nolan, J O'Sullivan and G Virgo (eds) Restitution Past, Present and Future: Essays in Honour of Gareth Jones (Oxford: Hart, 1998) p 251, at p 257.

${ }^{230}$ Edelman, above n 184, pp 325-326 and Edelman, above n 172. See Miller (2013), above n 20, pp 980-987.

${ }^{231}$ Miller (2011), above n 20, pp 270-271.

232 Miller (2011), above n 20, p 271.
} 